\title{
THE MAUSOLEUM OF SAINT FRUTUOSO NEAR BRAGA, IN PORTUGAL, AND THE TRANSIT OF BYZANTINE INFLUENCES IN EARLY MIDDLE AGES' EUROPE
}

\section{JORGE [MANUEL DE OLIVEIRA] RODRIGUES}

UDC: 7.033.2:726.822(469.112)"o6"

Preliminary communication

Manuscript received: 30. 11. 2015.

Revised manuscript accepted: 21. 03. 2016.

DOI: 10.1484/J.HAM.5.111335
J. [M. de Oliveira] Rodrigues IHA/DHA [Art History Institute/Department], FCSH-Universidade NOVA de Lisboa and Calouste Gulbenkian Museum Rua da Milharada, 23-8o Diro 2745-822 Queluz, Portugal jrodrigues@gulbenkian.pt

In the vicinities of Braga, one of the most important religious centres of the Iberian Peninsula, Saint Frutuoso is believed to have built a small centralized-plan building, in Montélios, probably intended to be his mausoleum. Different authors date it to a large time span, from the $7^{\text {th }}$ to the turn of the $11^{\text {th }}$ centuries, affliating the construction to artistic traditions as diverse as the Visigoth, Byzantine or Mozarabic. What we propose to discuss in this paper is not only the evidence that links the mausoleum to its 'Patron Saint', but also the obvious influences received and the misdeeds that it suffered with the restoration of the $20^{\text {th }}$ century, shuffing the available material evidence.

Keywords: Braga, Frutuoso, Montélios, Dume, centralized-plan, Visigoth, Byzantine, Mozarabic

\section{THE CENTRALIZED PLAN AND ITS USE IN PORTUGAL}

The use of a centralized plan for churches, martyria or burial architectural structures in Portugal is quite rare throughout the Middle Ages, especially when compared to the rest of Europe where the crossing of Antique, Byzantine and Carolingian influences produced a significant number of such structures. Following the ideal plan of the roman imperial mausoleums, the use of a centralized plan will be mediated through an emblematic building such as the roman Pantheon - transformed into a church in the $7^{\text {th }}$ century, as Santa Maria Rotonda - but mainly through its former and most significant symbolical reference: the Anastasis, the Holy Sepulchre, whose inventio is due to Constantine via his mother, Helena.

Despite its exceptional character, this architectural model was nonetheless used in the territory now corresponding to Portugal to receive the mortal remains of Saint Frutuoso, in a Greek cross plan mausoleum addorsed to the Monastery of the Saviour in Montélios [Fig. 1]. This monastery, founded by the Saint himself, is situated very near the city of Braga, which would later become the most important archiepiscopal see in the country. Replaced in 1523 by a new Franciscan convent, whose church was rebuilt around $1728^{1}$, it is through this church that we can still access the mausoleum of the Saint today, as it might have been the case in the original construction.

Two important similar examples precede the construction of São Frutuoso: the Montinho das Laranjeiras church in the South of Portugal, in the Algarve, and the basilica of São Martinho de [Saint Martin of] Dume, very close to
Braga and to Montélios. They embody the two main routes of penetration of this artistic model in Hispania, from the East Mediterranean and the Italic peninsula, under the influence of Byzantium. The first one is directly linked to the Byzantine occupation of the southern Iberian Peninsula between 551-552 and 624-625 - the ancient Anas, in the regions of the Baetica and of the southern Lusitania - with the most relevant influences arriving through Ravenna and southern Italy, namely via Sicily; the second one entailed the crossing of Gaul, following the pilgrimage routes established to worship the relics of Saint Martin of Tours, passing through the Alps by cities like Grenoble or Lyon².

The cruciform ecclesia of Montinho das Laranjeiras, near Alcoutim, in Algarve, was built between the end at the $6^{\text {th }}$ century and the beginning of the $7^{\text {th }}$, showing two distinctive constructive phases and some dissymmetry of its plan, still preserving some important tokens of its rich decoration of mosaic and marbles. Although of a more rustic nature, the building - which possibly survived the Mozarabic period, up to the Peninsular Reconquista [reconquest] ${ }^{3}$ - is a testimony to the use of an architectural plan of byzantine origin, even if in a simplified make.

The much more complex S. Martinho de [Saint Martin of] Dume basilica was founded by Martinus, Saint Martin of Dume, a monk of Hungarian origin that arrived at the far Northwest of the Iberian Peninsula by the middle of the 6th century. In his youth Martin visited the Holy Places in the Middle East, namely in Palestine, where he would have made contact with the desert hermits that seem to have inspired his fervent adherence to the virtues of the ascetic life of the monks, deprived of mundane pleasures and vices; he would 


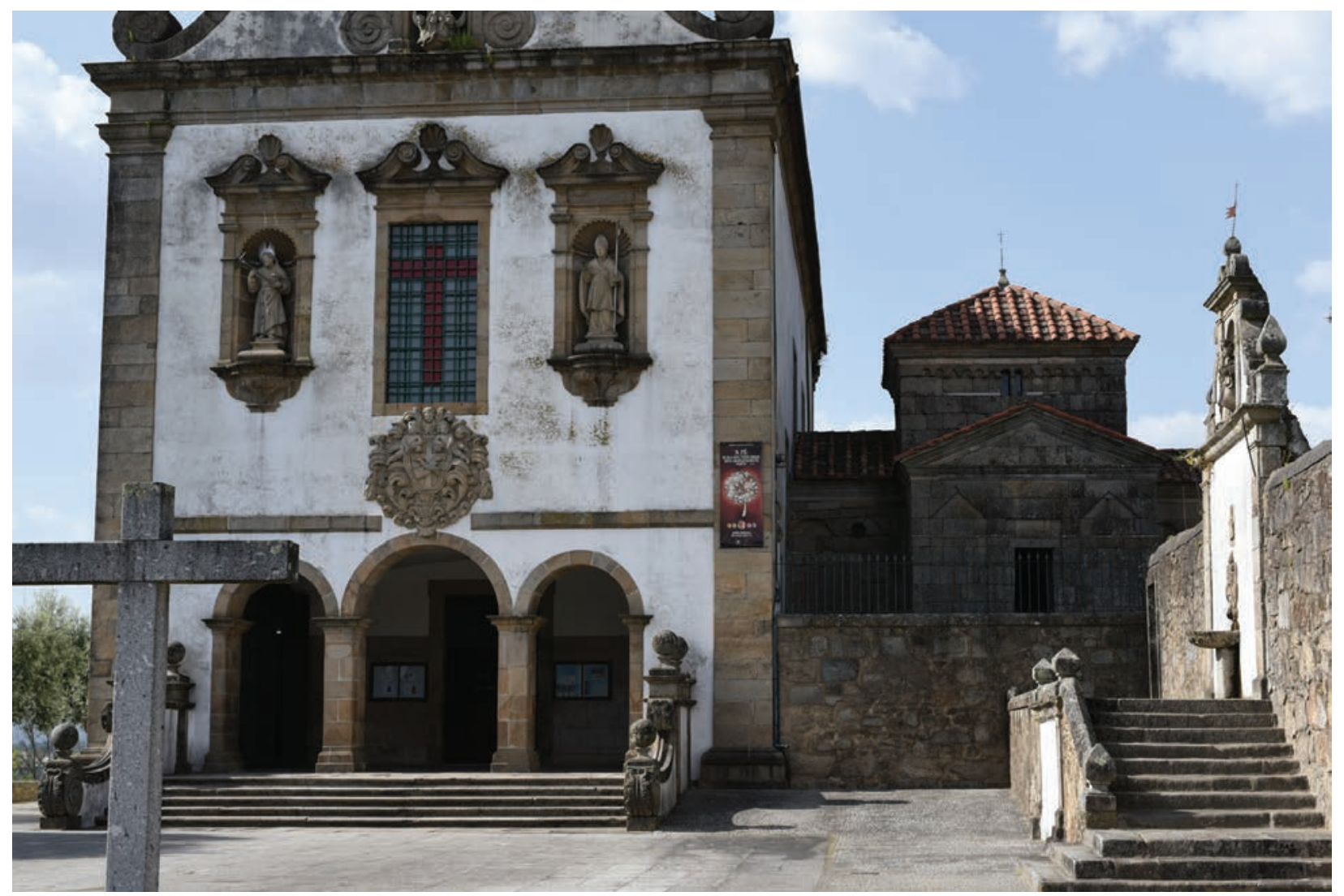

Fig. 1 - General view of the mausoleum of Saint Frutuoso of Montélios addorsed to the Franciscan church of the $16^{\text {th }} / 18^{\text {th }}$ centuries

later come to Galliciae, probably disembarking in Portucale [Oporto] in 550, at the very time when the emissaries of King Carrarico where arriving from Gaul, carrying the relics of Saint-Martin of Tours in order to obtain a miraculous cure for the king's son, Teodemiro. This providential coincidence seems to have dictated Martin's fortune at the Suevi court, as a religious and virtuous man, settling in Dume, in the outskirts of Braga where the basilica would be built: "Dume's basilica seems to function as the Palatine Chapel where the king and the court go to pray"4. His fortune grew rapidly inside the Suevi court, becoming not only the responsible for the erection of the cruciform basilica - that would serve as a royal monastery but also as the bishopric, in the same suburbia of Bracara where the Suevi kings would also build their Palace - but also the main religious protagonist at the said court 5 .

The monastery, of which he would become the first abbot, would follow the model of those that Martin had known in the East: in 556 King Carrarico would create, with him in mind, the new bishopric of Dume, of which he would also be invested as bishop in April fourth of the same year, with the particularity, unique in the West, of the monastic church - dedicated to the Saint bearing his name, SaintMartin of Tours ${ }^{6}$ - doubling as Cathedral of the new diocese in 558. In 569 Martin would finally ascend to the coveted title of Bishop of Braga, a post he would occupy until his death, in 579, joining it to the title of Bishop of Dume, that he would never abandon 7 . The decisions of the Council of Braga of $561^{8}$, held in the time of Martin of Dume - shortly before his ascension to the diocesis bracarensis and most likely induced by him as the influential man of the Suevi court - would prove of lasting influence in the way which burials were looked upon and banned from the holy ground of churches, monasteries and other sacred spaces throughout the final stages of the Early Middle Ages and the period ranging from the beginning of the new millennium up to the late $13^{\text {th }}$ century.

This basilica of Dume would be of paramount importance in the strategy of domination of the western strip of the Iberian Peninsula by the Suevi, from their arrival in 409 , until their loss of the kingdom to the Visigoths in 585 . The first folk - or tribe - of Germanic origin to dominate in a consolidated and continuous basis the western strip of territory of the Iberian Peninsula, that roughly corresponds to Portugal and Galicia were, in fact, the Suevi, originally professing the Christian Arian creed, since 465, and later integrating the Roman Church. The Visigoths would also follow the same conversion process from 550: arriving in 569, they would change the capital from Braga to Toledo in 507 - a central place for the effective control of the Iberian

${ }^{4}$ J. MACIEL, Antiguidade tardia e paleocristianismo em Portugal, Lisbon, Author's edition, 1996, pp. 82-86, here p. 85

${ }^{5}$ Ibidem, pp. 82-86

${ }^{6}$ MACIEL, op. cit. (n. 2), p. 749 and L. FONTES, O Norte de Portugal no período suevo-visigótico. Elementos para o seu estudo (offprint of XXXIX Corso di Cultura sull'Arte Ravennate e Bizantina), Ravenna, 1992, p. 226-236

${ }^{7}$ MACIEL, op. cit. (n. 2), p. 749 and FONTES , op. cit. (n. 6), p. 226-236

${ }^{8}$ MACIEL, op. cit. (n. 4), p. 78; X. DECTOT, Les tombeaux des familles royales de la péninsule ibérique au Moyen Âge, Turnhout, Brepols Publishers, 2009, p. 141; P. ARIÊS, L'Homme devant la Mort, Paris, Éditions du Seuil, 1977, p. 38, dates it of 563; I. BANGO TORVISO, El espacio para enterramientos privilegiados en la arquitectura medieval española, in Anuario del Departamento de Historia y Teoría del Arte, Madrid, Universidad Autónoma de Madrid, vol. 4, 1992, p. 93-132, here p. 94, points out the fact that this ban was mainly respected from the $7^{\text {th }}$ century, on the Iberian Peninsula 


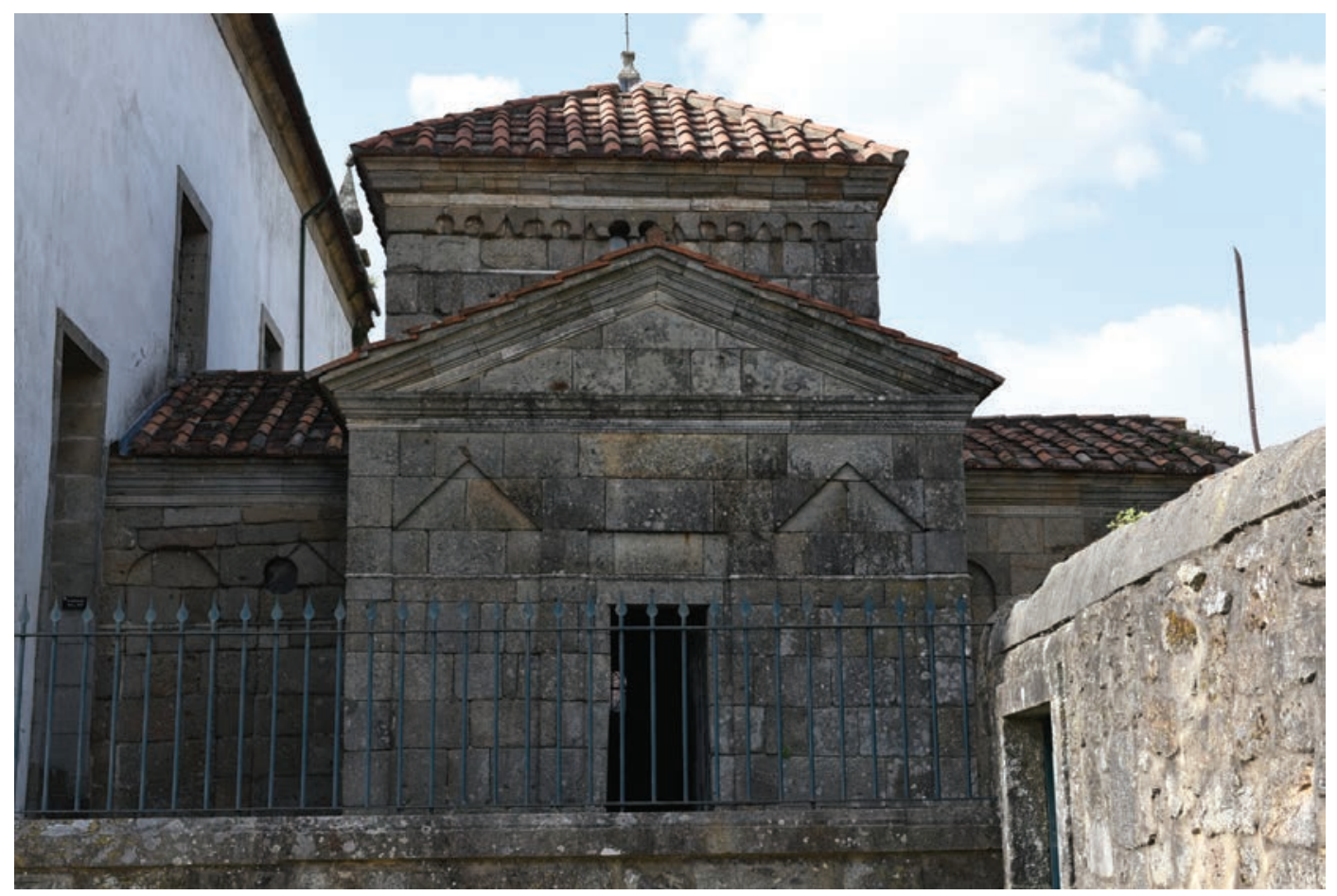

Fig. 2 - Western view of the mausoleum

Peninsula that they now dominated as a whole - later integrating the Suevi in their midst 9 .

The same models and influences - Byzantine, circulating through southern Italy and, especially, Ravenna - seem to be behind a similar architectural decision and consequent commission of Charlemagne that would later build his Palatine Chapel in Aquisgrana [Aix-la-Chapelle/Aachen] as an - almost - round church ${ }^{10}$, probably mimicking San Vitale of Ravenna and apparently also destined to be his place of memory ${ }^{11}$. The arrival, before the year 8oo, of the relics worshiped in this Marian church, and its obvious affinities with the Anastasis - but also with the temple of the Ascension of the Virgin, in Jerusalem - helps to explain the probable use of the palatine chapel as the mausoleum of Charlemagne, originally buried under the vast atrium ${ }^{12}$, in a more than likely harbinger of the galilees built before the forefront of many Romanesque churches, but here monumentalized set between the two tall towers of the façade - to enhance its Imperial significance ${ }^{13}$.

It is interesting to compare the way the Suevi court, in much earlier days, would closely tie and relate the Aulic structures of the Palace to the religious - and symbolic structures of the monastic church and - later - cathedral of the new bishopric. This was done in a very similar way not only to what the central European courts would do then and later - Merovingian and, mainly, Carolingian - but also to the Asturian ones of the $9^{\text {th }}$ century, very influenced by the first at architectural level - the Aula Régia of Naranco, in Oviedo, is a clear example - but also at diplomatic level ${ }^{14}$.

\section{THE MAUSOLEUM OF SAINT FRUTUOSO OF MONTÉLIOS}

Saint Frutuoso founded what we believe to have been built as his mausoleum still in the $7^{\text {th }}$ century and apparently leaned to the church of the monastery of the Saviour [Fig. 2], a tradition that would be kept even in the modern Era, after the destruction of the original construction of the monastic temple, allegedly by the advancing Moors. This hypothetic and much discussed destruction ${ }^{15}$, if it indeed took place, could only have occurred in the initial advance of the Islamic conquerors after 711 that - as it would later be the case of the Al-Mansur in Santiago de Compostela, in 997 - would ravage the churches but respect the sanctity of the shrines of the Christian Saints. At the time of the arrival of the Islamic ranks at the Peninsula, given the care they took to establish themselves as peaceful rulers in the territories previously

9 J. MACIEL, A Arte da Antiguidade Tardia (séculos III-VIII, ano de 711), in História da Arte Portuguesa (dir. Paulo PEREIRA), Lisbon, Círculo de Leitores, 1995, Vol. 1, p. 120 and 131

${ }^{10}$ Hexadecagonal on the outer perimeter, octagonal on the central area

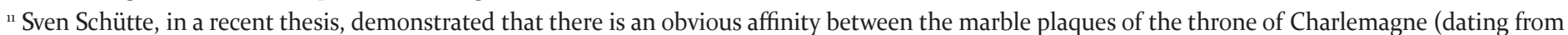
the period of the Emperor, around 798, probably also the date of the completion of the temple) and those found at the Holy Sepulchre, as quoted by S. BRAUN, Aix-la-Chapelle [Aachen],in Dictionnaire d'Histoire de l'Art du Moyen Âge occidental, Paris, Robert Laffont (dir. Pascale CHARRON and JeanMarie GUILLOUËT), p. 8-11, that also points out the obvious influence, on the plan of this palatine chapel, of the churches of Sergio and Bacchus from Constantinople (527-536) and, mainly, that of Saint Vitale of Ravenna, enshrined in 547

${ }^{12}$ Ibidem, p. 9-10: the archeological digs of 1910 unveiled here a ditch large enough to contain the sarcophagus of Charlemagne

${ }^{13}$ R. McKITTERICK, Charlemagne. The Formation of a European Identity, Cambridge: Cambridge University Press, 2008, p. 140-141, quotes a poem from the 9th century (after 814), the Lament over the death of Charlemagne, in which the Author mentions the 'grief' for the Emperor, "mourned as much in Rome as in France and buried in the ground in Aachen", a fact that constitutes a precious testimony to establish Aix-la-Chapelle as the inhumation place of the Emperor, but also to clearly establish his ascendant either over the Church - Rome - as over the State, that the territory of the Francs embodies

${ }^{14}$ Ibidem,

${ }^{15}$ ALMEIDA, op. cit. (n. 1), p. 124 


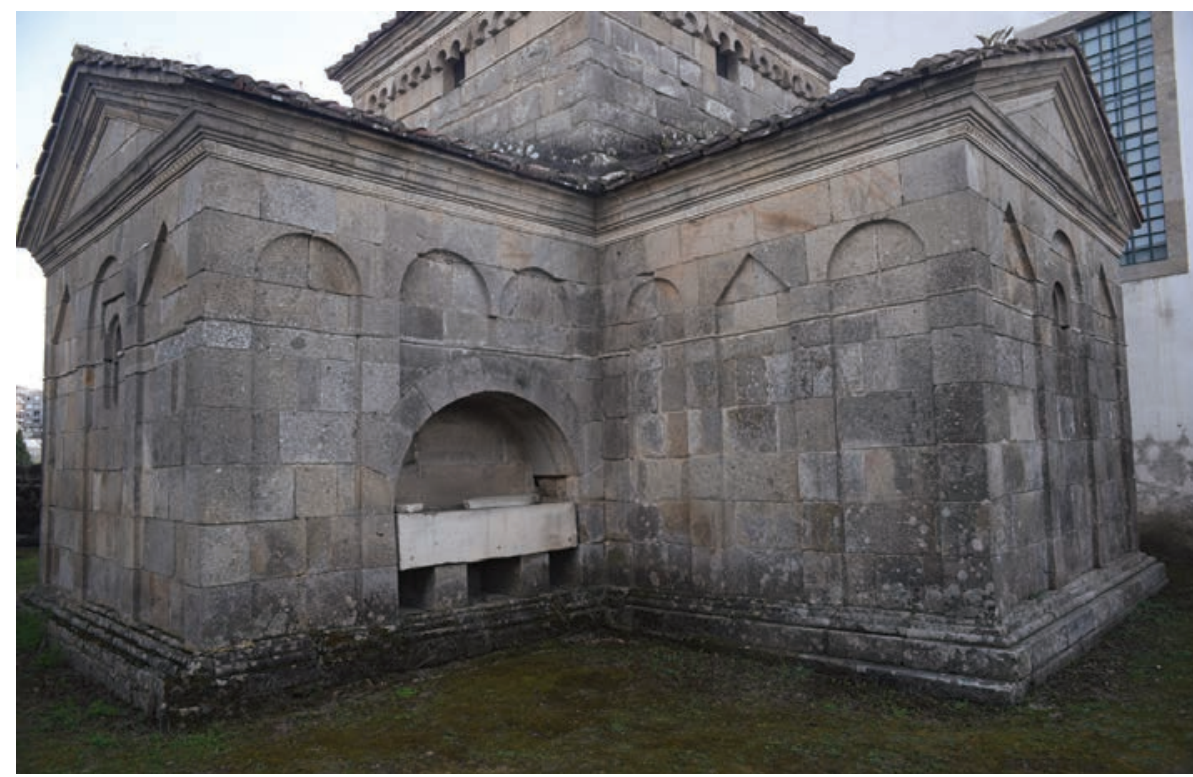

Fig. 3-East and south arms of the mausoleum, the last one with the arcosolium believed to have been the burial place of Saint Frutuoso (notice the alternate round and mitre-shaped blind arches) the mausoleum of Galla Placidia (originally linked to the church of Santa Croce, also destroyed) or the nearby church of San Vitale, both in Ravenna ${ }^{16}$ - to the Mozarabic ones. The chronicle of Saint Valério $(623-695)^{17}$ tells us the story of the demeanour and efforts of Saint Frutuoso to finish his work, just before his death, in $665^{18}$ :

"Meanwhile in a small hill, between the city of Braga and the moor of Dume, he built a monastery of great grade where is holy body was put to rest. He was so committed in the building of the holy monastic church, as I've acknowledged through a narration of the abbot Cassiano, a righteous servant of God, first disciple of the Saint, that having known of reliable source, and with great forethought, that his holy death was very near, that is to say, that the completion of his earthly life [was close by], at a time when the building of the monastery was already in an advanced stage, not only did he work without rest during the day but also, in the light of torches, during the night, [he] persevered to conclude the said works so that his passing would not find him with his doing unachieved. In such a way that, helped by the will of God, he piously conducted and fortunately consecrated what he had faithfully begun."19

Long is the list of authors that have dealt with this unique building in the Peninsular medieval architecture, with a central plan that gathers the three most perfect forms found in religious architecture: the circle (a half-sphere) from the dome of the crossing, inserted in a square that, in its turn, is inscribed in a almost perfect Greek cross, with arms of equal length.

One of the most significant ones is Fernando de Almeida, that made a comprehensive approach to Visigoth, Byzantine, Islamic and early medieval Mozarabic constructions that may have established some kind of affinity with the mausoleum of Montélios, as well as to the authors who have addressed it - Ernesto Korrodi ${ }^{20}$, Schlunk, Pedro de Palol $^{21}$, Gomez Moreno, Chamoso Lamas, Manuel Monteiro, Aguiar Barreiros, Moura Coutinho, Alberto Feio or Sérgio Pinto - discussing their proposals but denying, from the beginning, the thesis of the "levelling" of the burial chapel by Al-Mansur in 997. And this stating the obvious argument that the Bishop Gelmirez of Santiago de Compostela went there in 1102 in order to steal the relics of the Saint,

${ }^{16}$ This last one built by Justinian on the place of the sanctuary, where the mausoleum of Constantine had been erected, dedicated by the roman Emperor to the Apostles and sacred in 548, R. KRAUTHEIMER, A note on Justinian's church of the Holy Apostles in Constantinople, in Studies in Early Christian, Medieval and Renaissance Art, London, London University Press, 1971, p. 197-201, here p. 197

${ }^{17}$ Probably a monk of Montélios, as is suggested by M. C. DIAZ Y DIAZ, La Vida de S. Frutuoso de Braga. Estudio y Edición crítica, Braga, 1974, quoted by ALMEIDA, op. cit. (n. 1), p. 122-124

${ }^{18}$ R. SANTOS, O Românico em Portugal, Lisbon, Editorial Sul, 1955, p. 13-16

${ }_{19}$ S. VALÈRIO, Vida de S. Frutuoso, Braga, Livraria Cruz, 1978, p. 43-44; MACIEL, op. cit. (n. 4), p. 90-91 underlines that Saint Frutuoso, was a wealthy representative of the Visigoth nobility, what allowed him to patronize the construction of numerous monasteria and ecclesiae", and to enshrine the 'churches'- the basílica and the mausoleum - that he had built himself: "We can deduct from the final words in the Vita that Saint Frutuoso was buried in the ecclesia that he had built in cacumine modici montis between the city of Braga and the coenobium of Dume, that is to say, at the monasterium of the Saviour of Montélios.", p. 90

${ }^{20}$ That will have rediscovered, in 1897, the ancient mausoleum, disclosed in an article published in 1898 in the Boletim da Real Associação dos Architectos Civis e Archeologos Portugueses, quoted by L. FONTES, S. Frutuoso de Montelios, Braga, Comissão Regional de Turismo do Verde Minho, 1989, p. 6

${ }^{21}$ P. PALOL, Arte Hispânico de la Epoca Visigoda, Barcelona, Ediciones Poligrafa, 1968, p. 134-140, underlining the coexistence in the building of elements that refer to the Byzantine art of Ravenna - notably of Galla Placidia (Greek cross plan and the blind exterior arches) - along others distinctively 'Spanish Visigoths' (Corinthian capitals and frieze, but also the roofing system of the apses of the mausoleum) 
apparently kept in the arcosolium opened in the thickness of its walls on the outside ${ }^{22}$ [Figs. 3 and 4], in a compromise between the martyrium and the dispositions of the clergy of Braga quoted before, even if the construction was built on purpose to shelter him. Dating the building from the $7^{\text {th }}$ century, it is clear to Fernando de Almeida that Gelmirez couldn't have taken the relics if they weren't there anymore...

This belief of the Author makes perfect sense in view of the ban of burials inside the churches, decided at the Council of Braga of 561, that would make it impossible for Frutuoso to bury himself inside the temple at that stage: hence the reason for the hasty construction of his mausoleum, linked to the monastic church, and - even so - the strong possibility of the laying of his sarcophagus in the arcosolium opened in the outside wall. Only after his canonization could he be moved inside the building - something that we have no evidence of having ever happened - since the Saints were not dead but always living souls ${ }^{23}$. Fernando de Almeida considers this mausoleum to belong to the "Visigoth cycle", although with just a few influences from the Mozarabic period, probably added/transformed at a later stage ${ }^{24}$.

João Moura Coutinho, the architect from Braga that had an important role in the very controversial restoration of the building, also left an extensive monography - published posthumously, a quarter of a century after his death - where he subscribes to the thesis of the foundation of the building as the mausoleum of Saint Frutuoso, associated to the $7^{\text {th }}$ century monastic church "...despite the devastation caused by the infidels..." ${ }^{25}$. He seeks - and finds, in his view - the relevant artistic influences behind the construction of the mausoleum in the Byzantine context of Ravenna, not so much from Galla Placidia, whose similitudes with Montélios he considers more or less "superficial", but much more in the mausoleum of Theodoric and, mainly, in the Neonian and S. Giovanni in Fonte baptisteries "...where the constructive and ornamental details have closer affinities to those in the 'chapel of S. Salvador' of Montélios" 26.

Before Coutinho Sérgio da Silva Pinto had already advocated the thesis of the "byzantinism" of S. Frutuoso de
Montélios, dating it to the Empire's most glorious era $\left(9^{\text {th }}-11^{\text {th }}\right.$ centuries)" - never before the 1oth century and, with greater probability, from the $11^{\text {th }}$ century, due to the "...dome over the crossing, in the shape of a [spherical] cap and in brick, resting over pendentives, in the Byzantine style, but perched in stone corbels..." ${ }^{27}$. Helmut Schlunk, Gómez-Moreno and Aguiar Barreiros, with minor variations, will embrace the "Visigoth" thesis, placing the foundation of the monument in the $7^{\text {th }}$ century ${ }^{28}$.

Theodor Hauschild will, on his turn, trace the influences of the roofing system, with the spherical dome and the vaults designed with the intention of counterbalancing its weight and push, to other similar churches from the Visigoth period in the Iberian Peninsula; although not exempt of Byzantine influences in their constructive systems - that he traces directly to Galla Placidia - he will find a "Peninsular" originality in this tendentiously central plan in churches such as Santa Comba de Bande (Ourense) or San Pedro de la Nave (Zamora) ${ }^{29}$, closely following on this matter the thinking of Pedro de Palol ${ }^{30}$.

In recent years Justino Maciel, following the Vita Sancti Frutuosi ${ }^{31}$, underlines the importance of the references to the ecclesiae of the monasterium of Montélios, deducing that one of the 'temples', dedicated to the Saviour, would be intended to liturgical and community celebrations and the other, of martyrial, purpose, would serve as the mausoleum of Saint Frutuoso, which will be from the very beginning its patron saint ${ }^{32}$.

On the other hand both Manuel Monteiro ${ }^{33}$ and Alberto Feio 34 advocated not only the evidence of the destruction caused by Muslims, that would not have permitted the survival of a mausoleum from a saint from the Visigoth period - Manuel Monteiro even states that the Saint's tomb had been placed inside the monastic church that he had founded, dedicated to the Saviour, at the time of the Moorish invasion of $716^{35}$ - but also the dating of the building, Mozarabic ${ }^{36}$, to the $11^{\text {th }}$ century. This thesis will be enhanced by Alberto Feio who, quoting Pierre David, underlines the fact that the cult of Saint Frutuoso is only established from

\footnotetext{
${ }_{22}^{22}$ J. RODRIGUES, Galilea, locus e memória. Panteões, estruturas funerárias e espaços religiosos associados em Portugal, do início do século XII a meados do século XIV: da formação do Reino à vitória no Salado (Ph.D. thesis FCSH/Universidade NOVA de Lisboa), 2011, p. 402; opinion shared by BANGO TORVISO, op. cit. (n. 8), p. 106: the ban of 561 is fully respected, forcing Saint Frutuoso to place his sarcophagus in an "...arcosolio sobre el paramento exterior del templo."

${ }^{23}$ J. GEARY, Furta Sacra, Princeton, Princeton University Press (2⿺ ed.), 1990, p. 124; P. BROWN, The Cult of the Saints, Chicago, The University of Chicago Press (2 ed.), 1982, p. 113 f.

${ }^{24}$ F. ALMEIDA, Arte Visigótica em Portugal, Lisbon, 1962, p. 130-154, mainly p. 133 and 153-154

${ }^{25}$ J. COUTINHO, São Frutuoso, Braga, ASPA, 1978, p. 89 f.

${ }^{26}$ Ibidem, p. 72-75 and 78-83 [quote p. 81]

${ }^{27}$ S. PINTO, S. Frutuoso de Montélios. A igreja mais Bizantina da Península [offprint of Diálogo, suplemento de cultura, letras e artes of the Diário Ilustrado, March 11, 1958], Braga, 196o, p. 11

${ }^{28}$ Quoted by ALMEIDA, op. cit. (n. 1), p. 143

${ }_{29}$ T. HAUSCHILD, Arte Visigótica, in História da Arte em Portugal. Do Paleolítico à Arte Visigótica, Lisboa: Alfa, 1986, vol. 1, p. 149-169, here p. 166

$3^{30}$ See note 22

${ }^{31}$ See S. VALÈRIO op. cit. (n. 20), and M. C. DIAZ Y DIAZ op. cit. (n. 18), p. 155-178

${ }^{32}$ MACIEL, op. cit. (n. 9), p. 103-149, here p. 135; see also MACIEL, op. cit. (n. 2), p. 748-749, about the question of the addorsement of the mausoleum of Montélios to the adjoining basilica, as would be the case, in Ravenna, with Galla Placidia and the church of Santa Croce, that J.-P. CAILLET, Martyrium, in Dictionnaire d'Histoire de l'Art du Moyen Âge occidental, Paris, Robert Laffont (dir. Pascale CHARRON and Jean-Marie GUILLOUËT), p. 603-604

33 M. MONTEIRO, S. Frutuoso, uma igreja mozárabe, in Dispersos, Braga, ASPA, 1980, p. 251-279, namely p. 276-277

${ }^{34}$ A. FEIO, A arte da alta idade média no distrito de Braga [offprint of Bracara Augusta, vol. V, no 1-2 (26-27)], Braga, 1954, p. 5-12

35 MONTEIRO op. cit. (n. 34), p. 255-256: something that is hard for us to believe, not only because the Author has no hard evidence of what he claims, but also because there is an obvious conflict with the provisions of the Braga council of 561 , banning any burial inside the basilicas of the holy martyrs, ARIĖS, op. cit. (n. 8), p. 38 [this council of Braga is wrongly dated dated of 563]; MACIEL , op. cit. (n. 4), p. 78; BANGO TORVISO , op. cit. (n. 8), p. 94; DECTOT , op. cit. (n. 8), p. 141
}

${ }^{36}$ MONTEIRO op. cit. (n. 34), p. 266-268 


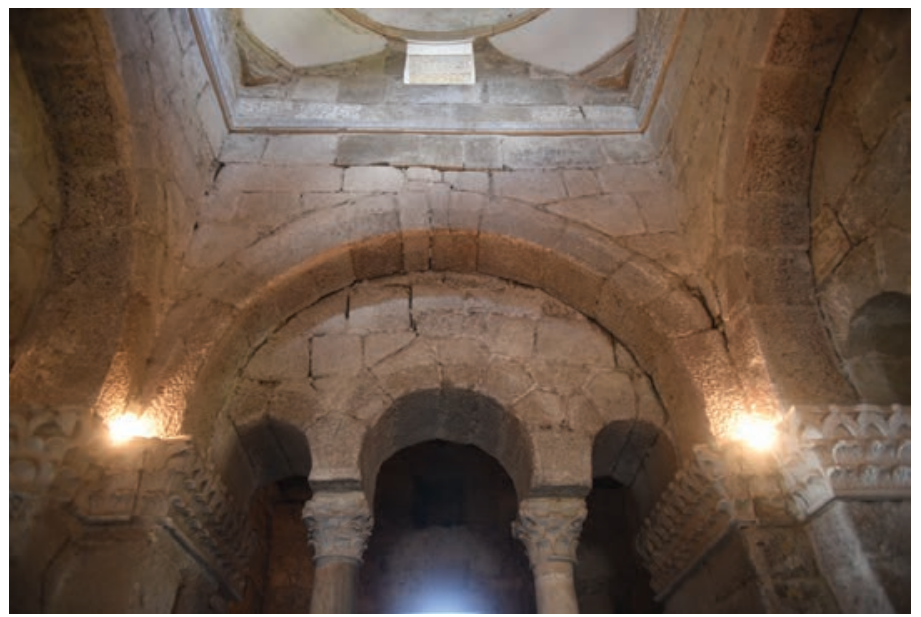

Fig. 5 - The interior crossing with the white marble frieze and capitals of the triple arches

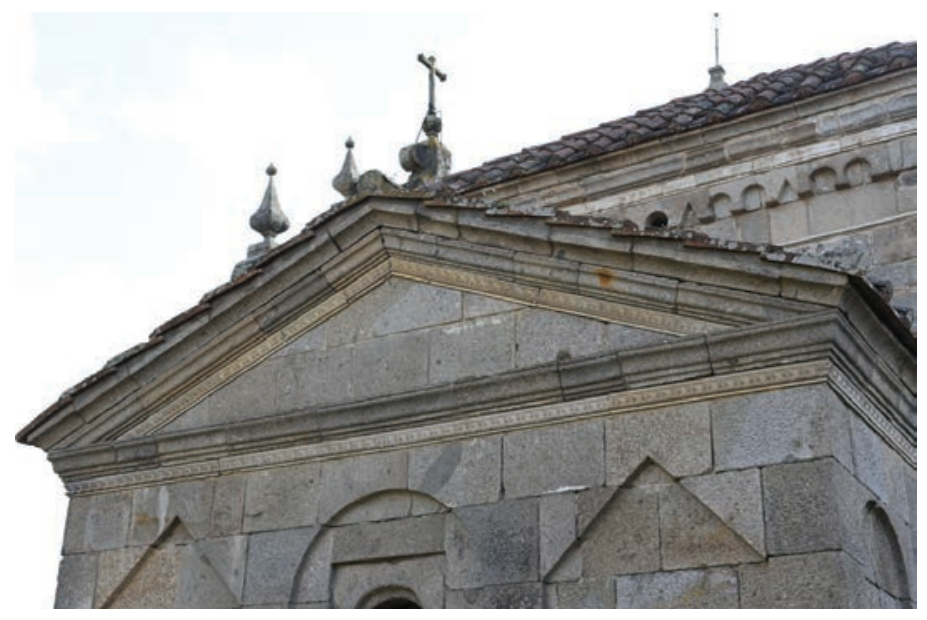

Fig. 6-South pediment detail showing the delicate white Portunhos limestone frieze

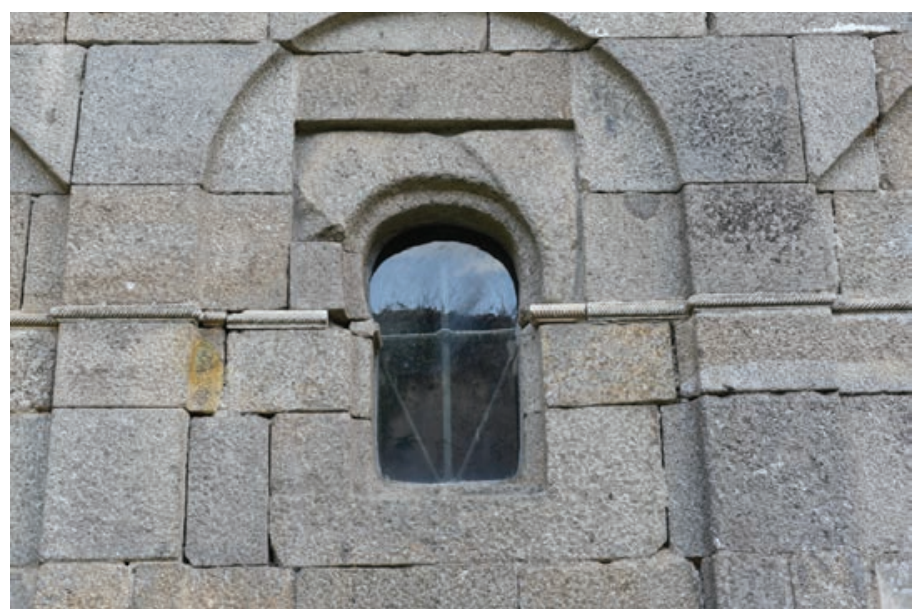

Fig. 7 - The east surpassed window and detail of one of the white limestone friezes that ornament the exterior walls the 11th century on, linking the limestone of Portunhos ${ }^{37}$ of part of its ornamental motives - both in the interior as in the exterior frieze of the pediment and walls [Figs. 5, 6 and 7] but also the constructive techniques applied in Montélios, to the important workshops and construction sites of the major Mozarabic artistic centre of Coimbra ${ }^{3}$.

The same view will be later favoured, with some nuances, by António de Azevedo, claiming that the very reasons that will have allowed the holy larceny perpetrated by Diego Gelmirez in 1102, in the case of Saint Frutuoso, were the same that had motivated Al-Mansur to preserve the tomb of Saint James in Compostela, whilst ravaging its cathedral: the respect for its remains but also for "the place where was placed the tomb of our saint" ${ }^{\prime \prime}$; a place that, contradicting Manuel Monteiro $^{40}$, is not a church and is not therefore subject to the dictates of the council of Braga of $561^{41}$. Azevedo continues by pronouncing the building to be of Visigoth origin, a baptistery, later transformed into a mausoleum with some 'exterior' similitudes with that of Galla Placidia; rebuilt in the nth century, with Mozarabic characteristics that Azevedo claims to have identified - namely in the apsidal vaults, that coexist with the "lovely primitive tiny windows". In such a way the Author would have found "...the two periods of the monument - the poor one from the 7th century, Byzantine, and the rich one, from the 11th century, more classical and with traits of Mozarabism...", denying, at the same time, the thesis of the Visigoth integrity of the building ${ }^{42}$.

The theory of Mozarabic origin was recently embraced by authors like Carlos Alberto Ferreira de Almeida, who closely followed the proposals of researchers such as Manuel Monteiro, although placing the construction of Montélios between the end of the $9^{\text {th }}$ century and the beginning of the $10^{\text {th }}$, considering the $11^{\text {th }}$ century an overly late dating ${ }^{43}$; the Author doesn't accept, either, that the building was a cella memoriae or a chapel-mausoleum but, instead "... a sanctuary to consecrate altars of relics. With three apses that housed as many small altars covered by stone baldachins, the temple was built to consecrate the relics and to worship the remains of Saint Frutuoso, and as such it could only have been made after his popular canonization" 44 .

The thesis of a late construction - although without any explicit reference to its possible Mozarabic origin - was later shared by Luís Fontes who, although accepting that this structure "... might have survived the Arabic invasions, it is acceptable that it could have been rebuilt at the time of the Christian Reconquista, accompanying the establishment of the cult of Saint Frutuoso" 45.

The long discussion about the construction, the artistic affiliation and the main influences of the mausoleum of Montélios is a symptom of the difficulties that art historians have come across, in the last decades, to correctly interpret

\footnotetext{
${ }^{37} \mathrm{~A}$ very fine and clear limestone quarry near Coimbra

${ }^{38}$ FEIO op. cit. (n. 35), p. 7 and 12

${ }^{40}$ MONTEIRO, op. cit. (n. 34), p. 268 walls of the basilica., p. 79

${ }^{42}$ AZEVEDO, op. cit. (n. 4o), p. 20 and 46-47

${ }^{43}$ ALMEIDA, op. cit. (n. 1), p. 122

${ }^{44}$ Ibidem, p. 124

${ }^{45}$ FONTES, op. cit. (n. 21), p. 6
}

39 A. AZEVEDO, O Mausoléu de S. Frutuoso de Braga, Braga, 1964, p. 19, that in the case of Compostela was literally confined to the Apostle's tomb, with the partial destruction of the cathedral that had rose above and around it

${ }^{41}$ MACIEL op. cit. (n. 4), p. 78-79: "All burials intra basilicam Sanctorum are banned, but they are allowed, if necessary, on the outside and around the 
the evidence of the material remains and of the - very scarce - documental evidence. And these difficulties became even greater when the then recently created DGEMN, DirecçãoGeral dos Edifícios e Monumentos Nacionais [General-directorate for the Public Buildings and Monuments] decided to start the restoration work in 1931, under the direction of the architects João de Moura Coutinho and Sousa Lobo. This followed a first attempt by Ernesto Korrodi, in 1897, to establish the original plan and fabric of what he considered to be a "Latin-Byzantine" construction ${ }^{46}$. The idea behind the restoration of the building, that the architects believed to have been built as the mausoleum of Saint Frutuoso, was subjacent to all the work, as was also the obvious similarity with the plan of Galla Placidia, despite all the doubts raised by Moura Coutinho that we have discussed earlier.

The possibility of an alternate plan to the one resulting from the restoration was also raised, namely in one proposed recreation of the building with an interior archery - like a "screen" - on the three terminal surpassed apses ${ }^{47}$, but this hypothesis is not supported by any material or documental hard evidence: the column bases that can be seen on the ground of one of these apses, in white marble [Fig. 11], are of modern manufacture and part of a final step of one version of the 'restoration' - more like a 'recreation', as we advocate - that was never accomplished. The exterior arcosolium also raised many questions, but the inspection of some of the older photographs taken during the works seem to vouch to its existence $a b$ initio, with only some minor repairs to its structure ${ }^{48}$. In most cases the 'impressions' of a later dating of the building are not based on any hard evidence, but mainly on more or less unfounded 'feelings' by the Authors that subscribe to it: for instance the use of surpassed arches in the plan of the apses, as in San Miguel de Escalada, does not contradict a common Visigoth affinity for both buildings.

A central problem identified by several authors, but mainly put into evidence by Ferreira de Almeida ${ }^{49}$, is the huge difference between the level of the floor of the present church and that of the mausoleum, which sits at a much higher quota. If we believe that the current temple replaced, on the same place, the original church of the Saviour, there is no easy (or logical) explanation for this gap. Only a future thorough archaeological intervention may help to shed some light on this conundrum.

A closer look at the building during its process of restoration - both the plan(s) as the rich photographic dossier of the work in progress ${ }^{50}$ - will show without a doubt that the similarities that we have identified with the Byzantine constructions from Ravenna are also shared with several Visigoth buildings of the Peninsula and, in particular with Santa Comba de Bande, not far from Braga. The main differences found seem to relate the building closer to what we believe to be its Visigoth make, namely the surpassed or horseshoe plan of the three apsidal arms (only the one connecting to the monastic church is rectangular) ${ }^{51}$; the small ajimez or biforae (only the one on the West façade remains

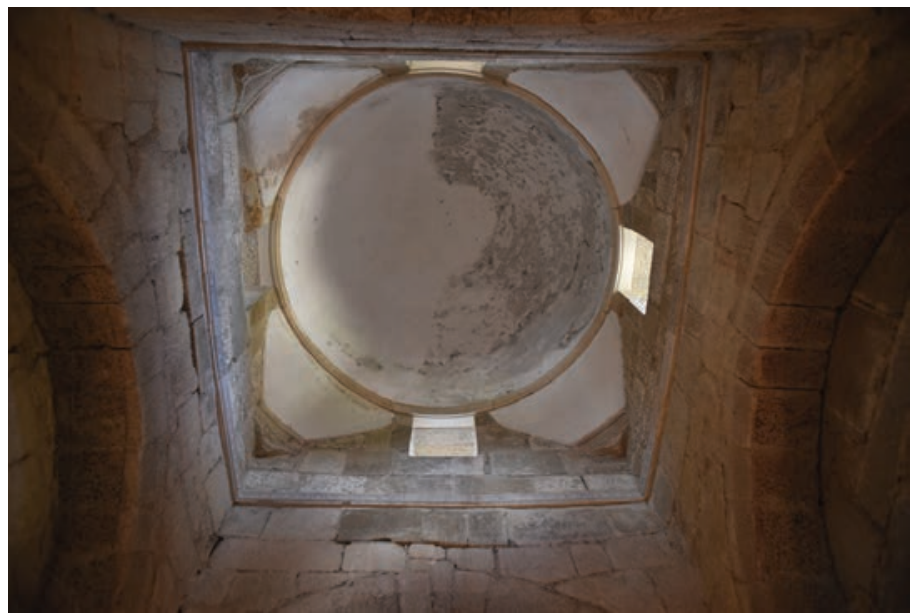

Fig. 8 - The dome of the crossing of Montélios seen from the inside

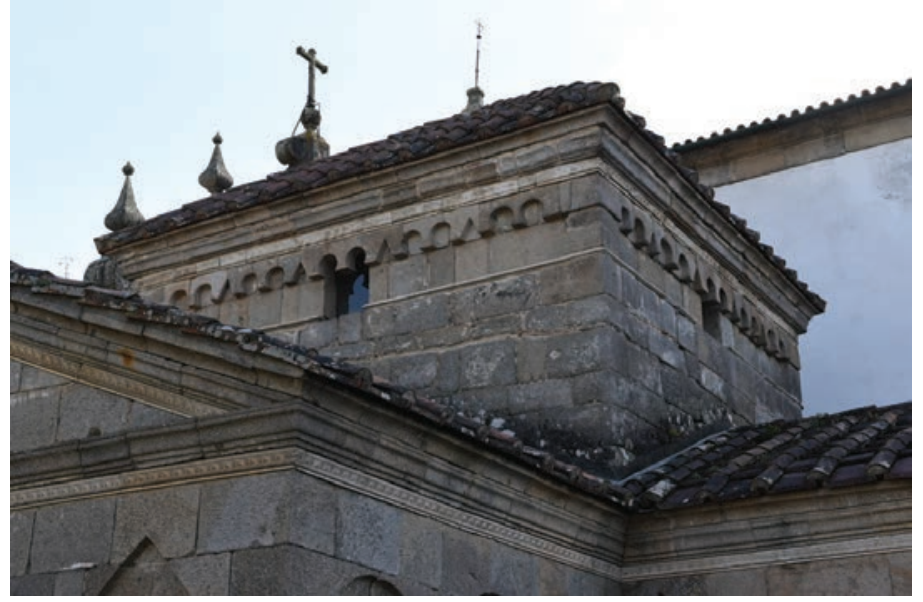

Fig. 9 - The exterior of the lantern-tower showing the frieze with alternating surpassed and mitre-shaped motives, and one of the small ajimez windows, truncated of the pillar

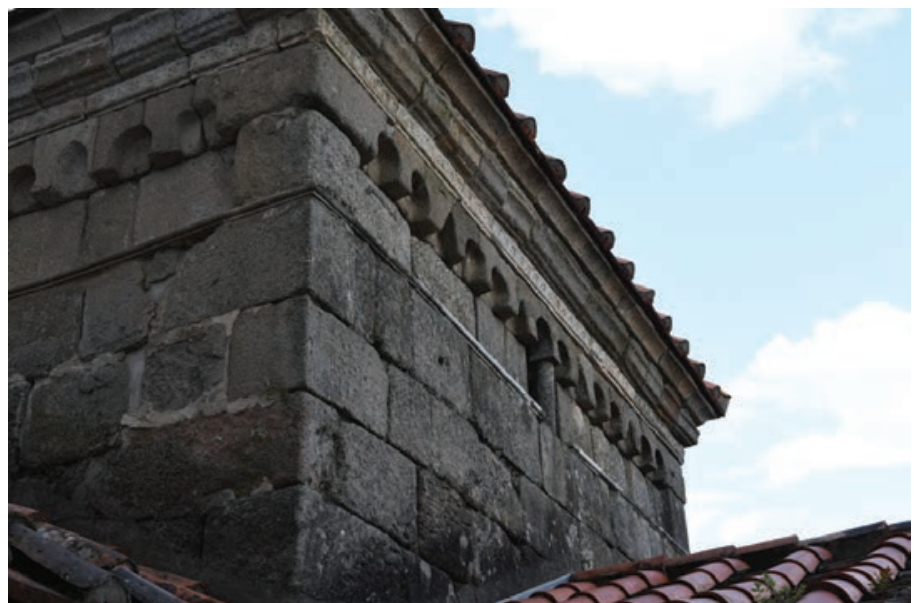

Fig. 10 - Detailed view of the west topside of the lantern-tower of Montélios, with the pillar of the ajimez still in place

intact), surpassed double windows lighting the interior of the crossing, under the dome [Fig. 8]; and the alternative-

\footnotetext{
$\overline{{ }^{46} \text { According to the inventory published in the official site of the ex- DGEMN }}$ - now the SIPA, from the Cultural Heritage General-directorate, DGEMNhttp:// www.monumentos.pt/Site/APP_PagesUser/SIPA.aspx?id=1903

${ }^{47}$ http://www.monumentos.pt/Site/APP_PagesUser/SIPA.aspx?id=1903 9 Desenho(s)/DES.00005702 and DES.oooo5711

${ }^{48}$ http://www.monumentos.pt/Site/APP_PagesUser/SIPA.aspx?id=1903 48 Fotografia(s)/FOTO.oo042027 and FOTO.ooo42044 namely

${ }^{49}$ Ibidem, p. 128

${ }^{50}$ http://www.monumentos.pt/Site/APP_PagesUser/SIPA.aspx?id=1903

${ }^{51}$ http://www.monumentos.pt/Site/APP_PagesUser/SIPA.aspx?id=1903 9 Desenho(s)/DES.oooo5701
} 


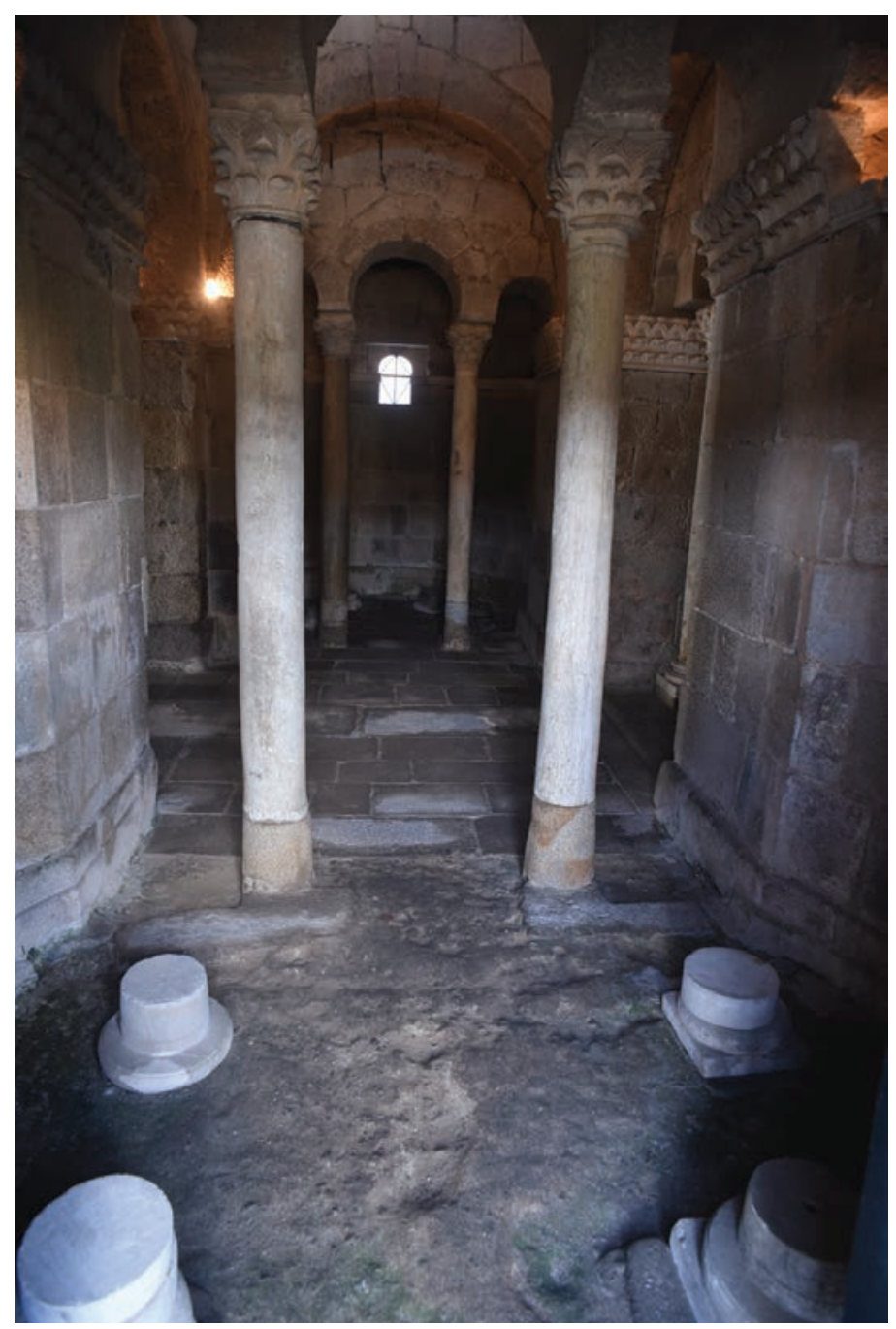

Fig. 11 - Interior of the opposed apses showing the white marble bases carved during the restoration process

ness of surpassed and mitre-shaped motives on the frieze that decorate the exterior of the central tower all around the construction [Figs. 9 and 10], repeated on the blind arches carved into the side walls, where only the wall supporting the arcosolium is different [Fig. 3].

This frieze, whose classical origin seems undisputed, is part of what we can categorize as the touch of sophistication of the building, side by side with the use of the Portunhos limestone elements, both in the interior as on the external walls and pediments. Although relating to its use in the Mozarabic architecture, this kind of ornamentation is also known to having been frequently employed in Byzantine architecture $^{52}$, here with the local 'twist' of the surpassed arches that are totally distinctive of the Iberian architecture of the Early Middle Ages. On the other hand these classical and Byzantine influences are also very present in the building, not only on its plan - something that we consider to be

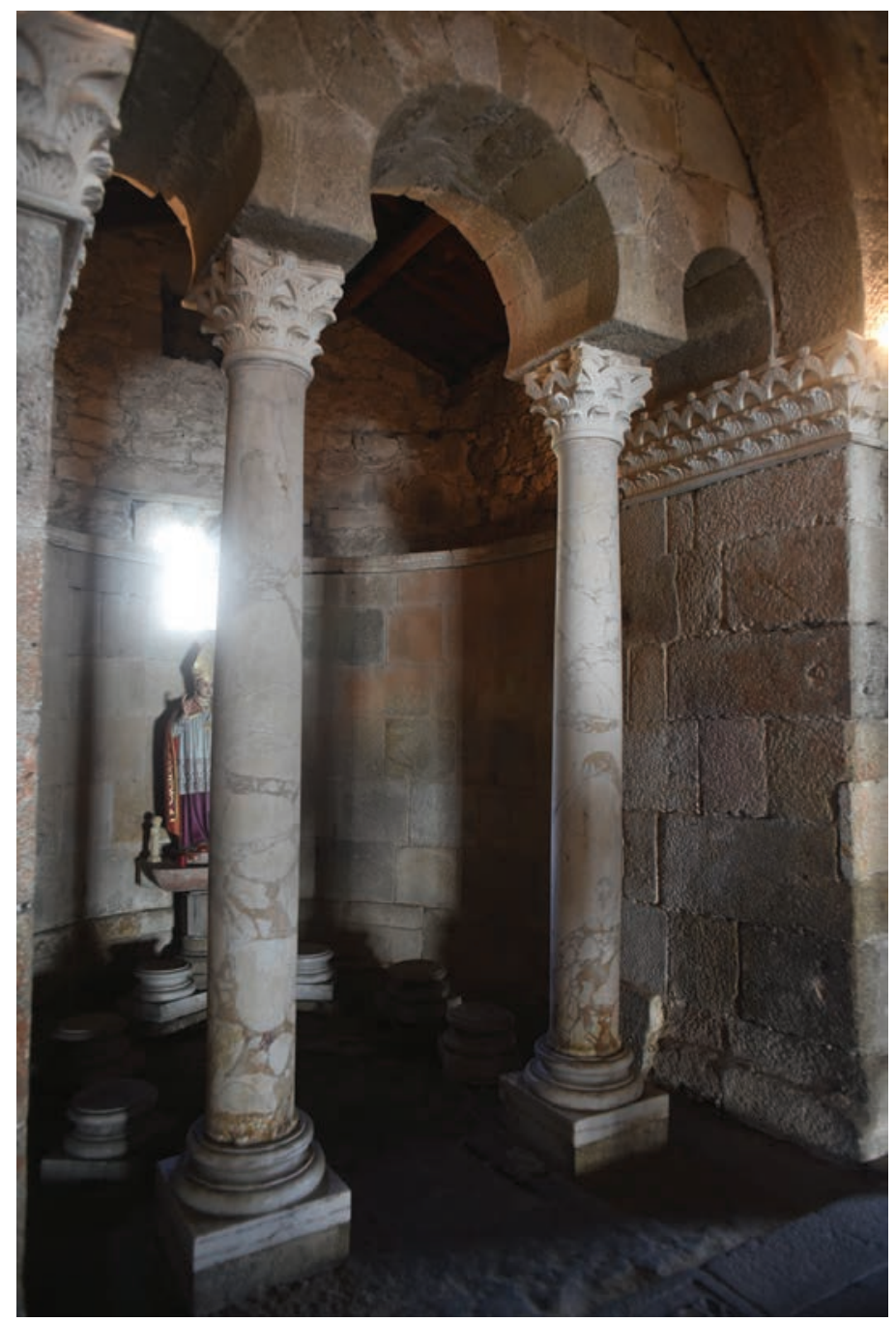

Fig. 12 - Detail of the triple arches, capitals and frieze

undisputable - but also in the pediments that end its three free arms and, mainly, in the Corinthian capitals and interior frieze - much of which remade during the restoration to match the few original parts remaining - carved in white limestone in blatant contrast with the dark tone of the granite stone used on the structure, in well-cut ashlars [Fig. 12].

The most significant approach to the Byzantine architecture is nevertheless emphasised by the presence of the triple arches ${ }^{53}$ dividing the arms of the Greek cross from the central crossing, [Figs. 5, 11 and 12] very similar to those used in Ravenna, namely in San Vitale, that would be later reproduced throughout the Christian world - under the byzantine-italic influence we referred to before - namely in the Palatine chapel of Charlemagne in Aquisgrana. The only difference is that here, betraying its Visigoth heritage, these arches are surpassed...54

\footnotetext{
${ }_{52}$ ALMEIDA, op. cit. (n. 1), p. 127

53 http://www.monumentos.pt/Site/APP_PagesUser/SIPA.aspx?id=1903 48 Fotografia(s)/ FOTO.oo042030 and FOTO.00539623

${ }^{54}$ João de Barros, in his Geographia D’Entre Douro e Minho e Tras-os-Montes, originally published in 1548, mentions 22 marble columns that supported the Franciscan Capuchin "House", little and cross-shaped, that seem to be at the origin of the proposed reconstruction of the $20^{\text {th }}$ century that we mentioned earlier: besides being virtually impossible to accommodate such a large number of columns inside the small mausoleum, is this a reference only to the mausoleum or also to the ensemble that it formed with the monastic church, rebuilt in 1523 and fairly new at the time it was visited by the Author?
} 